\title{
EN LA ENCRUCIJADA. EL RENACIMIENTO Y LA ERA GLOBAL O EL DIÁLOGO ENTRE EXPERIENCIA Y EXPECTATIVAS ${ }^{1}$
}

\author{
JOSÉ ANGEL ACHÓN INSAUSTI \\ Universidad de Deusto
}

\begin{abstract}
RESUMEN: La era global es un tiempo de incertidumbre en el que los referentes de la Modernidad ya no nos satisfacen. El artículo propone un «viaje» a otra época - el Renacimiento- en la que el ser humano afrontó una experiencia similar y en la que surgieron esos referentes ahora en crisis. La lectura de ese tiempo como época de encuentro de ideas, de generación de nuevos conceptos y utopías, de triunfo de unos proyectos y abandono de otros, es clave para afrontar con experiencia crítica las incertidumbres de nuestro presente.
\end{abstract}

PALABRAS CLAVE: Renacimiento, globalización, humanismo, política, estado, historia de la ciencia, racionalismo, Modernidad, identidad, libertad, historia conceptual, experiencia.

\section{At the crossroads. The Renaissance and the global age or the dialogue be- tween experience and expectations.}

ABSTRACT: The global age is a time of uncertainty in which the referents of the Modernity do not satisfy us anymore. This article proposes a journey to another age - The Renaissance- in which humans faced a similar experience and when those referents, now in crysis, emerged. The interpretation of this time as an age when ideas encountered, when new concepts and utopias were generated, when some projects triumphed and others were abandoned, is the key to face with critical experience the uncertainties of our present.

KEY WORDS: Renaissance, globalization, humanism, politics, state, history of science, rationalism, Modernity, identity, freedom, conceptual history, experience.

1. De cómo se propone al lector un Viaje al Renacimiento y, de paso, SE le inVita A CONSIDERAR EL VALOR DE LA EXPERIENCIA

"Cuando nos falla la razón, usamos de la experiencia" (M. de Montaigne)2

Decía Descartes que «es casi lo mismo conversar con gentes de otros siglos que viajar» y otorgaba a ambas actividades el mérito de ayudarnos a «no creer que todo lo que sea contrario a nuestras modas es ridículo y opuesto a la

1 Este texto desarrolla y amplía el contenido de la lección inaugural del curso 2014-15 impartida en la Universidad de Deusto el 12 de septiembre de 2014. Se inscribe también en el marco del proyecto de investigación del Ministerio de Economía y Competitividad HAR201348901-C6-4-R, «El proceso de la modernidad. Actores, discursos y cambios, de la sociedad tradicional a la revolución liberal, s. XVI-1850». Este artículo está dedicado a la memoria de mi padre, Ángel Achón, que me educó en la pasión por los libros

2 Ensayos completos, ed. Muñoz, A. y Picazo, M. D., Cátedra, Madrid, 2003, Libro III, cap. XIII, pág. 1012. 
razón» ${ }^{3}$. Aunque al padre del Racionalismo esta virtud le parecía claramente insuficiente, no viene mal recordar el paralelismo en este texto que quiere ser de Historia y que también quiere proponer al lector un viaje. Un viaje al pasado. Un viaje al Renacimiento.

¿Y por qué al Renacimiento? Una época llena de comparaciones sugerentes con nuestro tiempo. Se ha querido ver en ella una "primera globalización», creo que exageradamente. Pero es cierto que entonces se produjo una expansión de los horizontes geográficos que transformó valores y actitudes y reorientó comportamientos económicos y estructuras políticas. Si hablásemos de una época en la que el ser humano, al calor de una revolución tecnológica, se interroga por el alcance de su razón y de la ciencia, incrementa exponencialmente su movilidad, adapta sus estructuras económicas y políticas a nuevos horizontes de alcance mundial, reconsidera sus percepciones de la identidad colectiva y de las relaciones con el «otro», se plantea cómo educar a los ciudadanos ante tanta transformación e incertidumbre y quiere responder con creatividad e innovación ante los nuevos retos, costaría diferenciar si se trata del siglo XVI o del siglo XXI. Y no por casualidad.

Pero no va a ser sólo un viaje de placer. No queremos caer en el error que denunciaba Descartes cuando comparaba la historia con un viaje: «el que emplea demasiado tiempo en viajar acaba por tornarse extranjero en su propio país» y el que estudia lo sucedido en la historia «permanece ignorante de lo que se practica en el presente» ${ }^{4}$. De hecho, buscamos precisamente lo contrario. Si se me permite una aparente paradoja que en el fondo no lo es, diría que este es un texto de Historia y, por lo tanto, preocupado por la sociedad actual; preocupado no tanto por lo que fuimos como por lo que somos y lo que podríamos llegar a ser; preocupado por nuestra capacidad no para predecir el futuro, sino para situarnos ante él.

Como muy bien nos ha recordado Koselleck ${ }^{5}$, el tiempo presente es siempre un cruce de experiencias y expectativas. El pasado ya no existe y el futuro todavía no está aquí, pero al interpretar científicamente el pasado lo convertimos en experiencia racionalizada. Y esa experiencia sí está aquí y ahora; es una suerte de «pasado presente» que nos permite afrontar el hoy y el mañana conscientes de lo mejor y de lo peor de todo nuestro bagaje vital. Paralelamente, las expectativas funcionan como un «futuro presente» que aglutina nuestras acciones en torno a proyectos, ilusiones o utopías. La contribución de la Historia a nuestra sociedad consiste, precisamente, en establecer una mediación

\footnotetext{
3 Descartes, R., Discurso del método. Meditaciones metafísicas, ed. de Manuel García Morente, Espasa-Calpe, Madrid, 1979, pág. 39.

4 Descartes, R., o.c., p. 39.

5 Koselleck, R., Futuro pasado. Para una semántica de los tiempos históricos, Paidós, Barcelona 1993, pp. 333 ss. Sobre la recepción de Koselleck en España, véanse, a modo de ejemplo: Oncina, F. (ed.), Teorías y Prácticas de la Historia Conceptual, CSIC, Madrid 2009; Fernández Sebastián, J. y Capellán de Miguel, G.,Conceptos políticos, tiempo e historia. Nuevos enfoques en historia conceptual, Universidad de Cantabria - MacGraw-Hill, Santander, 2013.
} 
entre experiencias y expectativas. No porque nuestro futuro pueda leerse en sus antecedentes, sino porque el «sentido» que damos a nuestra interpretación del pasado orienta, y de manera sustancial, esas propuestas y expectativas.

Nuestra expectativa de partida es clara: reformular un humanismo apto para el siglo XXI, para la era global. Hemos vivido mucho tiempo precisamente del humanismo que comenzó a forjarse en el Renacimiento, pero es obvio que necesita una adaptación a los nuevos desafíos de nuestra era. Fernando Montes nos ha recordado que hay que ver en esta necesidad una oportunidad, y que «repensar el humanismo es tarea de la universidad ${ }^{6}$. Considérese este texto como una muy modesta aportación a esta tarea de largo alcance.

Una experiencia que pueda contribuir a orientar dicha expectativa: esto es lo que queremos concluir de nuestro viaje al Renacimiento. Pero para ello, ese viaje que les proponemos no puede ser el de la «tournée» oficial, el de los monumentos y rutas preestablecidas. Será, si se me permite la expresión, un viaje «de mochila y zapatillas», que exige salir de los circuitos oficiales y ver sitios que no se enseñan habitualmente. Una visita oficial al Renacimiento nos mostraría sólo lo que en esa época hay de nuevo y triunfante, un momento revolucionario que establecería una frontera clara entre el mundo moderno y los «oscuros» siglos medievales. Sin negar su carácter ciertamente innovador, hace tiempo que los historiadores han abandonado una imagen tan simplista ${ }^{7}$. El Renacimiento se interpreta hoy como un momento mucho más abierto, de transición, en el que el hombre, consciente de que se está abriendo una nueva época, se pregunta hacia dónde ir y formula opciones. El Renacimiento, en suma, no sería tanto el punto en el que surgen las claves de la Modernidad y del humanismo moderno como el momento en el que éstas, todavía embrionarias, se debaten con otras, resultando el conjunto mucho más rico en matices. En general, se nos muestra como un «caldo de cultivo» de ideas entre las cuales, ciertamente, podemos distinguir las «modernas», pero también otras que, arrinconadas en los siglos siguientes, quedaron ahí, en nuestro subconsciente colectivo. Es curioso que algunas de ellas estén reflotando ahora, evidentemente bajo formulaciones diversas, adaptadas a nuestro mundo. Nuestro objetivo es recuperarlas, comprenderlas en su inicio, con la esperanza de que esa experiencia acreciente nuestro bagaje para escoger y formular nuestras expectativas de futuro con más criterio.

6 Montes Matte, F. SJ, «La Universidad Jesuita como nuevo Proyecto Humanista», en: AUSJAL, Encuentro Mundial de Universidades Jesuitas, Universidad Iberoamericana: Documentos, México, 2010, pp. 4 y 10. (www.ausjal.org/documentos_rectores.html, consultada el 4 de julio de 2014).

7 Un ejemplo de revisión del período medieval en Heers, J., Le Moyen Age. Une imposture. Editions Parrin, Paris, 2008. Sobre el Renacimiento, BuRke, P., El Renacimiento europeo. Centro y periferias, Crítica, Barcelona, 2000. 
2. De Cómo El hombre SE SITUÓ EN EL CENTRO DE LA CREACIÓN Y DE CóMO, PARADÓJICAMENTE, EL PROGRESO DEJÓ DE SER HUMANO, AÑADIÉNDOSE ALGUNAS CONSIDERACIONES SOBRE EL TIPO DE CONOCIMIENTO QUE CONVIENE EN TIEMPOS DE INCERTIDUMBRE

"QQué generosidad sin igual la de Dios Padre y qué altísima y admirable dicha la del hombre! Le ha dado tener lo que desea y ser lo que quiera" (G. Pico della Mirandola) ${ }^{8}$

\section{El hombre en el centro del mundo}

El primer «itinerario» de nuestro viaje tiene que ver con el propio ser humano, con su posición en el mundo, con el objeto y alcance de su saber, con la capacidad de transformar su entorno y humanizarlo, y nos traslada a Roma a comienzos de septiembre de 1512. Allí encontramos a Miguel Ángel, muy preocupado porque su familia está en Florencia y Florencia está a punto de ser atacada por las tropas del Papa y de la Monarquía Católica, que acaban de arrasar Prato. Pero lo encontramos también a punto de concluir su célebre bóveda de la Capilla Sixtina. Fijémonos en un detalle de la misma, en el fresco de la Creación: la mano de un Dios pletórico de energía transmitiendo la Vida a Adán a través de un simple roce con su dedo. Esa mano y ese gesto contienen, simbólicamente, muchas de las claves del pensamiento humanista y resulta llamativo su paralelismo con las primeras páginas del Discurso sobre la dignidad del hombre de Giovanni Pico della Mirandola, uno de los emblemas del humanismo ${ }^{9}$. Casi a modo de trasunto iconográfico del texto de Pico, el gesto del Creador — que ya no es un Pantócrator medieval_ parece señalar al hombre como figura única de la Creación, como único ser que comparte características divinas y animales, obligado a elegir entre ellas y, por ello, radicalmente libre: «puede ser lo que quiera». Igualmente, es el único ser capaz de admirar la Obra divina y queda situado para ello «en el centro del mundo», como figura central de la Creación que puede «tener lo que desea». Y todo ello, como descubrirá enseguida Pico, obliga a conocer, a saber, pues no es posible «juzgar y amar aquello que no se conoce».

Así que es la propia condición humana, el desarrollo de la radical libertad con que Dios creó al hombre, lo que impulsa a éste hacia un nuevo mandato divino: saber y conocer. El Renacimiento fue consecuente con esta convicción y se volcó en la búsqueda del conocimiento a través de diferentes vías. Con el

8 "Discurso sobre la dignidad del hombre", en: Humanismo y Renacimiento, selección de textos de P.R. Santidrián, Alianza, Madrid, 1986, p. 123. Sobre el concepto de «dignidad humana» en esta época véase Pele, A., El discurso de la «dignitas hominis» en el humanismo del Renacimiento, Dykinson, Madrid, 2012.

9 Pico, o.c., pp. 122-126. Debemos recordar que, en su juventud, Miguel Ángel estuvo muy cerca de los neoplatónicos de la Academia de Filosofía de Florencia y en toda su obra puede apreciarse cuánto le marcó esa experiencia. De hecho, Miguel Angel ingresó en la Academia de Bellas Artes (sita junto a la anterior en el jardín de los Medici) en 1489, sólo tres años después de que Pico redactase su «Discurso». 
arte, decía Alberti, «nosotros los pintores queremos por los movimientos del cuerpo mostrar los movimientos del alma». A través de los estudios históricos y filológicos se puede comprender a los clásicos, como preconizaban los humanistas. Se puede conocer también mediante la observación directa, como comenzaba a hacer Copérnico, precisamente por estas fechas ${ }^{10}$. También los saberes más tradicionales como el Derecho, la Teología o la Filosofía conocieron una importante renovación, sobre todo por parte de los neoescolásticos. Otros, como Leonardo da Vinci, se obsesionaban con traducir sus observaciones a invenciones prácticas. Los hombres del Renacimiento debatieron mucho sobre la validez de estos saberes y se quejaron de cómo algunos pretendidos sabios los pervertían ${ }^{11}$, pero creo que se puede destacar que, en conjunto, apostaron por todos ellos y particularmente por su aplicación práctica, incluida la de los saberes más especulativos. Los neoescolásticos, por ejemplo, abandonaron algunas discusiones bizantinas de sus predecesores para aplicar su lógica deductiva al perfeccionamiento del ius gentium; igualmente, los humanistas se afanaron en la lectura de la historia, sobre todo de Roma, buscando lecciones prácticas para el gobierno de sus repúblicas. En general, parecía predominar la idea de que si Dios era indiscutiblemente el Creador, al menos había dotado al hombre de creatividad y dar cauce a esa creatividad era la mejor forma de manifestar lo específico de la condición humana y de cumplir con el nuevo mandato divino ${ }^{12}$.

10 La cita de Alberti en su Della Pittura, Libro II. Tomo la referencia de TenEnTI, A., Florencia en la época de los Médicis, Sarpe, Madrid, 1985, pág. 143. Copérnico, precisamente en 1512, se instalaba definitivamente en Frombork - de vuelta de sus estudios en Italia- y comenzaba a difundir entre sus amistades un escrito elaborado años antes donde ya avanzaba algunos extremos de su teoría heliocéntrica (véase N. Copérnico, Sobre las revoluciones (de los orbes celestes), ed. de Mínguez Pérez, C., Tecnos, Madrid, 2009, pág. XXIX ss. También Koyré, A. (y rev. de E. Rosen), «La revolución copernicana», en: TATON, R. (dir.), Historia General de las Ciencias, vol. II. La Ciencia Moderna (de 1450 a 1800). Primera Parte: El Renacimiento, Orbis, Barcelona, 1988, pp. 72-73.

11 Montaigne, por ejemplo, prefería la educación personalizada y no en centros educativos, pues los profesores «conocen bien a Galeno, mas no al enfermo» (MonTaIGne, o.c. pág. 176). Erasmo abominaba de los escolásticos, pues «no saben de nada y sin embargo pretenden conocerlo todo... qué suavemente deliran... como si estuvieran en el secreto de la naturaleza... No obstante, la naturaleza se ríe magníficamente de ellos y de sus conjeturas» (Erasmo de Rotterdam, Elogio de la locura, ed. de Suero Roca, T., Sarpe, Madrid, 1984, pág. 144). Leonardo también fue especialmente crítico con algunos eruditos: "yo no citaré otros autores, pero será mejor y más digno leer lo que diré basado en la experiencia que es maestra de sus maestros. Críticos hinchados y pomposos, van vestidos y adornados con galas ajenas» (en su "Códice Atlántico», cita tomada de Ottino della Chiesa, A.; Pomilio, M. (ed.), La obra pictórica completa de Leonardo, Noguer, Barcelona, 1969, pág. 589). Pero en ese mismo «Códice», el propio Leonardo cuenta que en su biblioteca tenía obras de humanistas como Dante o Petrarca, de clásicos como Ovidio, Vitrubio, Plinio o Esopo, y de autores cristianos como Alberto Magno o Isidoro y, por supuesto, la Biblia.

12 Paracelso opinaba que en los seis días fue creada la materia, pero no el Arte, reservado a la creatividad humana (tomo la idea de Glacken, C. J., Huellas en la playa de Rodas. Naturaleza y cultura en el pensamiento occidental desde la Antigüedad hasta finales del siglo XVIII, Ediciones del Serbal, Barcelona, 1996, p. 431). Sobre el uso del pasado en esta época, Burke, P., El sentido del pasado en el Renacimiento, Akal, Madrid 2016. 
De hecho, este impulso creativo no sólo se manifestó en el arte sino sobre todo en un proceso de innovación técnica que venía larvándose y produciendo resultados desde tiempo atrás. Ese proceso innovador no sólo generó un impulso económico interno sino que, además, permitió que los europeos se abriesen a nuevos mundos. Efectivamente, la mejora sustancial de las técnicas de navegación y de construcción naval permitió una ampliación sin precedentes de los espacios conocidos y dominados. A su vez, estas expediciones, viajes de descubrimiento y conquista fueron el mejor ejemplo de lo que el hombre era capaz de hacer. Los filósofos podían decir muchas cosas sobre las potencialidades del ser humano, y difundirlas gracias precisamente a otro invento, el de la imprenta. Pero lo que realmente veían muchas gentes llanas que ni leían ni escuchaban a los filósofos era que podían viajar a sitios remotos y vencer los obstáculos que les ponía la naturaleza. No había mejor lección práctica que ésta sobre la centralidad del hombre en la Creación. Y, en conjunto, no cabía duda de que el progreso técnico se traducía en una visible ampliación de opciones en la vida cotidiana del hombre, al menos del hombre europeo.

El Renacimiento fue, en este sentido, una expansión, una auténtica explosión que llevó al hombre a los confines del planeta. Con un matiz importante para nosotros: esa expansión se produjo sobre un entorno natural todavía desmesurado, inconmensurable, casi tan infinito en la Tierra como en el universo que empezaba a explorar Copérnico. No había límites ni para el conocimiento ni para la capacidad de expansión. Y quizá ello explique el optimismo con el que se asumió este nuevo rol del ser humano, liberado por un Dios que ya no le maneja a su antojo - al revés, le ordena ser libre-, capaz de superar toda suerte de riesgos y obstáculos naturales. Pero quizá también por ello, por esa inconmensurabilidad, esa expansión por el espacio y ese dominio de la naturaleza fueron perfectamente compatibles con el asombro respetuoso ante la misma, particularmente por parte de sus mentes más cultivadas. Recordemos que Pico ya nos había dicho que el hombre fue creado para admirar el sentido y la belleza de la Creación. Al mismo Pico, desvelar «los milagros escondidos en las cavernas del mundo, en el seno de la naturaleza» le parecía «magia» que «casa el cielo con la tierra», que «admira la obra de Dios» para, desde esa contemplación, inclinarse el hombre a explorarla, a conocerla. Leonardo no se cansó de repetir que la Pintura, lo mismo que la Poesía, «imitan tanto como es posible a la naturaleza». El mismo Leonardo, o filósofos como Ficino, loaron al Sol, como metáfora de la «luz divina» cuya visión nos acerca a la verdadera sabiduría $^{13}$. Los libros y crónicas de los viajeros y expedicionarios están llenos de descripciones y preguntas curiosas sobre «los secretos maravillosos» de la naturaleza ${ }^{14}$. Predomina, en suma, una visión de la realidad «como vida universal

13 GARIN, E., Marsilio Ficino y el platonismo, ed. preparada por A. Battán, Alción Editora, Córdoba, 1997, pp. 72-73.

14 PIco o.c., pp. 147-148; sobre Leonardo y Ficino, Garin, E., Ibid., pp. 72-73 y El Renacimiento italiano, Ariel, Barcelona, 1986, pág. 157. Sobre las maravillas de la naturaleza puede verse de Cárdenas, J., Problemas y secretos maravillosos de las Indias, ed. de Durán, A., 
y amor universal, luz e inteligibilidad universal», una visión integrada de toda la Creación, por mucho que el hombre ocupase el lugar central en la misma, una visión en la que no debe extrañar que la Filosofía fuese «entendida como visión conjunta del hombre y del mundo» ${ }^{15}$.

\section{El mundo está por todas partes}

La mano de Miguel Ángel nos ha revelado un imaginario social en el que un ser humano, libre, ocupaba el puesto central de la Creación, manifestaba su condición humana a través de la creatividad y del conocimiento, y gracias a todo ello dominaba lo creado sin dejar de admirarlo. Hagamos un pequeño alto en el camino, para descansar y reflexionar sobre lo que hemos visto.

Si comparamos el mundo del Renacimiento con el nuestro, quizá reparemos en que hoy seguimos compartiendo un entusiasmo notable por los avances científicos y tecnológicos pero combinados con buenas dosis de desencanto, incluso temor, acerca del uso que podamos dar a estos logros. Las películas de ciencia-ficción, siempre con las esperables dosis de exageración, suelen proyectar nuestros miedos con notable eficacia visual. En alguno de los clásicos del género se nos invita a asistir a auténticas pesadillas tecnológicas, como Blade Runner, dirigido por Ridley Scott en $1982^{16}$. El film presenta un escenario desolador en el que, sin embargo, la ciencia ha llegado a fabricar vida humana

\footnotetext{
Alianza, Madrid, 1988. También el arte generó imágenes bien reveladoras, como «La batalla de Alejandro en Issos», pintada por el alemán Albrecht Altdorfer en 1529, un motivo clásico que funciona como vehículo para mostrarnos una naturaleza casi inabarcable, un teatro majestuoso en el que tienen lugar las acciones humanas y en el que, ante su magnitud, la individualidad de cada protagonista se vuelve insignificante. Un escenario que, no por casualidad, tenía ya como centro al Sol. Por cierto, no parece sino que Altdorfer, lo mismo que Ficino o Leonardo, estuvieran preparando intelectualmente la llegada de las teorías de Copérnico.

15 Garin, E., «El filósofo y el mago», en: Garin, E. (ed.), El hombre del Renacimiento, o.c., pp. 179 y 185.

16 Se ha dicho de este film que es «la película postmoderna por excelencia» (Lyon, D., Postmodernidad. Alianza, Madrid, 1996, pág. 11). Está basado en la novela de Dick P. K., ¿Sueñan los androides con ovejas eléctricas?, escrita en 1968. Hay edición en castellano, en Edhasa, Barcelona, 1992. En la pelicula, la ciudad de Los Ángeles se presenta, a la altura de 2019, como un escenario inhabitable en todos los sentidos: hay tanta contaminación que nunca se ve la luz del sol y los habitantes más ricos han huido del planeta; no se aprecia que haya sociedad, ni grupos sociales, sólo individuos que vagan aislados en una mezcolanza de etnias que refuerza más la sensación de falta de identidad; no hay un pasado que proporcione sentido — sólo ruinas-, ni al parecer futuro; tampoco se ve vida animal... Un escenario desolador. Eso sí, el progreso técnico y científico ha llegado al punto en el que el hombre es capaz de "crear» vida humana artificial: «Más humanos que los humanos» es el lema de la empresa o industria que fabrica a los «replicantes», que son capaces de desarrollar sentimientos y memoria, de tener miedo a la muerte, que están obsesionados con su «fecha de caducidad», que son tan perfectos que no pueden distinguirse de los realmente humanos; de hecho, el espectador duda constantemente sobre las cualidades morales de unos y otros.
} 
artificial, indistinguible de la natural. En suma, el hombre ya no sólo es creativo, sino que también compite con el Creador. Pero, en medio de la desolación, ¿es ése un progreso con sentido humano? ¿es un progreso al servicio del hombre? O, al revés, ¿es el hombre el instrumento de un progreso sin sentido?

Hay quien ha afirmado que la mayor diferencia entre la expansión del siglo XVI y la globalización actual es que en el primer caso la innovación técnica se aplicó a la naturaleza y en el segundo al hombre y a la vida ${ }^{17}$. De hecho, este fenómeno ha provocado de entrada que nuestro imaginario sobre el mundo ofrezca un cambio sustancial con respecto al renacentista. Hasta hace unos decenios la imagen con la que se explicaba el progreso humano seguía teniendo mucho que ver con la de una expansión. Si en el Renacimiento el hombre había llegado a los confines del planeta, en los años 60 del siglo XX pisó la Luna, y a partir de ahí todos nuestros imaginarios empezaron a proyectarse sobre la expansión hacia el universo. Pero desde que las tecnologías de la comunicación han «encogido» el planeta y la interdependencia avanza en muchos ámbitos de nuestras vidas, la metáfora ha cambiado: ahora es más bien la de una implosión, la de una explosión hacia dentro. No vamos a espacios nuevos, es el espacio global el que se nos viene encima, a nuestro pequeño mundo local, a nuestras vidas cotidianas. Como ha dicho Galli, «el mundo está por todas partes» ${ }^{18}$ y altera de forma sustancial nuestros ritmos de vida. Los avances científicos y tecnológicos han modificado, en primer lugar, nuestras relaciones sociales. Hoy son los campos de la información y de la comunicación los más característicos de este fenómeno, los que encarnan como ningún otro la realidad de un mundo interconectado, y los que nos traen nuevos problemas como el del acceso a la información, el de sabernos mover críticamente en el mundo de la sobreinformación, o el de la presencia de mundos virtuales en nuestra vida cotidiana ${ }^{19}$. Pero donde nuestro asombro - y nuestro temor- sigue sin

17 Tomo la idea de Eloy García, en su estudio preliminar a J.G.A. Pocock, El momento maquiavélico. El pensamiento político florentino y la tradición republicana atlántica, Tecnos, Madrid, 2002, p. 51.

18 Galli, C., Espacios políticos. La edad moderna y la edad global. Léxico de política, Ediciones Nueva Visión, Buenos Aires, 2002, pág. 40.

19 Por muy revolucionaria que fuese - que lo fue- la imprenta en su tiempo, no existe punto de comparación con la multiplicación de la cantidad de información puesta a nuestro servicio que supone - y aun supondrá más - internet. El protagonista de «El giro» (Greenblatt, S., El giro. De cómo un manuscrito olvidado contribuyó a crear el mundo moderno, Crítica, Barcelona, 2014), el humanista Poggio Bracciolini, se emocionaba al encontrar clásicos perdidos en los monasterios, porque el acceso a la "poca» información existente y la capacidad de leerla, traducirla y entenderla, eran las garantías para el acceso al conocimiento en la época. Aunque los problemas de acceso a la información darán todavía mucho que hablar, nuestro caso es prácticamente el contrario: nuestro problema ya no es tanto - y de momento- el acceso a la información, como nuestra capacidad para movernos críticamente en torno a ella, de orientarnos entre la sobreinformación que no garantiza el conocimiento, más bien al contrario. Por otro lado, la multiplicación de posibilidades (y necesidades) de comunicación ha traspasado el límite de lo visible hasta el punto de hacer de lo virtual una realidad cotidiana. 
tener límites es ante la incursión de la ciencia y de la tecnología en la vida. Independientemente de la cuestionable verosimilitud del argumento y situación reflejados en Blade Runner, el film nos plantea algunas realidades ya ciertas como la ingeniería y la industria genéticas que, a su vez, nos obligan a replantear por enésima vez el tema de las consecuencias morales de nuestro progreso. Nadie podría, ni debería, dejar de admirarse e ilusionarse ante las estimulantes perspectivas que estos avances prometen en la lucha contra determinadas enfermedades, en el aumento de la esperanza de vida o en la mejora de la calidad de la misma. Pero nadie puede, ni debe, dejar de preocuparse por algunas de sus implicaciones, que van desde el problema de la sobrepoblación, hasta el de los límites del uso de estas tecnologías, el de la lucha contra nuevos tipos de delincuencia, o el de la desigualdad en la distribución social de los beneficios de estos avances.

Además, los antecedentes invitan al pesimismo. La ciencia y la tecnología - símbolos máximos de la creatividad humana moderna- se han revelado tan potencialmente constructoras - cuando pensamos en los avances de la medicina o de las comunicaciones- como destructoras del hombre y de su medio - desde el momento en que somos capaz de imaginar y construir un potencial bélico suficiente como para acabar con la vida en la tierra-. Además, hemos descubierto que la naturaleza es, en cierto modo, finita, que no admite que la sigamos considerando, exclusivamente, como «recurso" y que su explotación intensiva también pone en cuestión la sostenibilidad de la vida en el planeta, o al menos las condiciones en las que lo habitarán futuras generaciones. De alguna manera, este fenómeno, es exactamente el inverso al que se produce en el Renacimiento: una sensación de potencial finitud frente a la anterior inconmensurabilidad.

El problema no se refiere sólo a nuestros usos concretos de los avances científicos y tecnológicos, sino que, creo, va más allá y alerta sobre nuestras concepciones de progreso y desarrollo. No hay tiempo para detenerse aquí en la importante cuestión de cómo se ha llegado a perder esa estrecha hilazón entre un progreso medido en términos de crecimiento material, y un progreso humano medible en términos de incremento de opciones para las personas, pero bastará con recordar un dato. Que una institución como la ONU —poco sospechosa de ser considerada «anti-sistema»— haya propuesto la creación de un Índice de Desarrollo al que ha tenido que adjetivar como «Humano» para distinguirlo del concepto de desarrollo predominante, indica bien a las claras el valor meramente instrumental que lo humano estaba y está alcanzando en nuestras formas de concebir y fomentar el progreso ${ }^{20}$.

Todo esto explica que lo característico de nuestra época sea una mezcla de asombro y escepticismo o desencanto cultural. Asombro, porque nuestra capacidad de conocimiento científico e innovación tecnológica sigue extendiéndose

20 Véase Jolly, R.; Emmeris, L.; Weiss, T. G., El poder de las ideas. Claves para una historia intelectual de las Naciones Unidas, Los Libros de la Catarata, Nadrid, 2007, pp. 84-85. 
de manera y a campos que antes no imaginábamos. Escepticismo, porque nuestro progreso cultural y moral no garantiza un uso «humano» de esos avances, ni el sentido «humano» de nuestro desarrollo.

\section{Saber en tiempos de incertidumbre}

Algo que entendieron perfectamente los hombres del Renacimiento y quizá hayamos olvidado es que acercarse al sentido de la existencia humana, comprender lo humano como categoría central de nuestro pensamiento y acción, pensar la naturaleza desde la admiración, como casa del hombre, además de conocerla en su funcionamiento y de construir artefactos e ingenios para domesticarla... todo ello exigía y exige una comprensión del conjunto tanto o más que de una de las parcelas del saber. De hecho, hay quien ha definido al hombre del Renacimiento como «sobre todo aquel que ha abandonado los confines de los distintos campos de la acción y del saber». Los ejemplos son numerosos y conocidos (Leonardo, Copérnico, el propio Pico, etc.) y siempre nos conducen a una "extrema dificultad para trazar una línea entre el artista, el científico, el moralista y el filósofo» ${ }^{21}$. Ya comentamos cómo los hombres del Renacimiento debatieron mucho sobre la aportación de cada uno de estos saberes, pero no parecieron dudar mucho cuando se trató de su propio proceso formativo: la gran mayoría combinó distintos tipos de conocimientos, a veces de forma enciclopédica. En casos como el de Erasmo, hay incluso unas irónicas quejas sobre cómo llegan a pervertirse las diferentes esferas del saber cuando se encierran en sí mismas o cuando el saber es mera vanidad ${ }^{22}$. Creo que el mensaje que nos

21 GARIN, «El filósofo y el mago», pp. 176 y 184. En la pág. 177 se incluyen más ejemplos. También en «La cultura florentina en la época de Leonardo», en su Medioevo y Renacimiento. Estudios e Investigaciones. Taurus, Madrid, 1981, pp. 223 y ss. Copérnico era doctor en Derecho canónico y compatibilizaba labores de médico con el servicio a la Iglesia, a la vez que iniciaba sus observaciones astronómicas (Koyré, o.c. pág. 72). Ficino era médico, filósofo y escritor; Poliziano, filósofo y jurista, como tantos otros; Benivieni combinaba estudios humanísticos con los de anatomía; Leonardo fue capaz de pintar, inventar, observar la naturaleza y escribir loas al sol; Pico enumeró los saberes fundamentales y en su enumeración aparecían la filosofía moral, la filosofía natural, la dialéctica, la contemplación del cielo sideral, las artes liberales, la teología, la ciencia de los números, e incluso la magia o la cábala (Pico, o.c, pp. 223 ss.). Sobre la magia en la época, véase García Fernández, E., "Cultura, Ciencia y Magia en la Edad Media», en su Cultura de élites y cultura popular en Occidente (Edades Media y Moderna), Universidad del País Vasco, Bilbao, 2001, pp. 109-141.

22 Erasmo, en su Elogio de la locura, ironizó sobre distintos tipos de «sabios»: el gramático «que sería feliz por completo si pudiera vivir lo suficiente para determinar la manera de distinguir las ocho partes de la oración» o que «considera casi como motivo de guerra confundir una conjunción con un adverbio» (o.c. p. 137); los juristas cuya obsesión en urdir leyes «sin importarles que vengan o no a pelo, acumulando comentario sobre comentario, opinión sobre opinión y haciendo creer que sus estudios son los más difíciles de todos» (o.c. pp. 142-143); los teólogos, que «viven en el quinto cielo» (o.c. pág. 146) y son capaces, con sus disquisiciones, de concluir que «es más leve delito degollar mil hombres que coser en 
lanzan es que para comprender la función particular de un saber, de una destreza concreta, su contribución al desarrollo humano, es imprescindible tener una comprensión de lo global, de lo sistémico, una comprensión más integral del conjunto de transformaciones y objetivos en los que se inserta aquel saber particular. Mucho más en momentos de cambio e incertidumbre. Por eso al hombre renacentista no le asustaba combinar saberes especulativos y humanísticos con otros más prácticos y científicos. De igual manera, no pocos pensadores argumentaron que el verdadero conocimiento comienza por el de uno mismo, por su interioridad, por la «experiencia personal... (de) zambullirse en las profundidad de la propia alma», o debatieron sobre el equilibrio entre vida activa y contemplativa, discutiendo la primacía de una u otra ${ }^{23}$.

Está bien claro que el nivel de especialización que ha alcanzado la ciencia en nuestros días impide cualquier tipo de tendencia hacia un saber enciclopédico. Nadie quiere renunciar a una especialización que es la madre del rigor científico y de nuestra capacidad de penetrar en los secretos del hombre y de la naturaleza a través del análisis. Pero es curioso, por ejemplo, que reclamemos continuamente el valor de lo interdisciplinar. Me pregunto, en suma, si no sigue quedando latente una pregunta de fondo: el conocimiento en profundidad ¿se adquiere sólo mediante la especialización? ¿no necesitamos comprender, ya no la utilidad, sino el sentido, lo que cada parcela del saber significa para el progreso humano? En consecuencia, cuando formamos a nuestros jóvenes para enfrentarse a un mundo progresivamente más complejo, el camino ¿es sólo el de la especialización? Pensando, por ejemplo, en el ya mencionado campo de la aplicación de tecnología a la vida, no sé cómo lo afrontaremos si no fomentamos nuestra capacidad de prepararnos para estos desafíos en términos de otros saberes o «inteligencias» como las que, según Gardner o Torralba, preparan al hombre para situarse a sí mismo ante «los rasgos existenciales de la condición humana» y ante las experiencias profundas (amor, muerte) que acompañan esa existencia, o le ayudan a «crear valores para encontrar el sentido y significado de nuestros actos» ${ }^{24}$. No sé tampoco si un ingeniero genético o un empresario

domingo los zapatos de un pobre» (o.c. pp. 148-149). También ironiza sobre otros, menos sabios, como los «artistas de profesión... de los cuales el de menos valor es el que posee más insolente presunción» (o.c. p. 119); o los que cultivan las nuevas ciencias ocultas, buscando «no sé qué quintaesencia por tierras y mares» (o.c. p. 109). Incluso sobre la medicina, pues «sobre todo como hoy la ejercen algunos no es otra cosa que una forma de adulación, no menos que la retórica» (o.c. p. 96).

23 La cita en GARIN (Marsilio Ficino o.c., pp. 68-69) hablando de Ficino. Sobre las discusiones entre vida activa y contemplativa, véanse, por ejemplo, los textos de Salutati (en GaRín, El Renacimiento o.c., pp. 103-108). También el ejemplo de Cristoforo Laudino (en GARIN, El hombre o.c., p. 185) que, además de protagonista de esta discusión, fue «exponente de la nueva orientación cultural, un técnico, pero también un estudioso de matemáticas y de óptica, un gran tratadista de pintura, escultura y arquitectura» y estuvo «inmerso en los problemas de la sociedad contemporánea, de la ciudad y de la familia».

${ }^{24}$ Véase por ejemplo Torralba, F., Inteligencia espiritual, Plataforma Editorial, Barcelona, 2010, pp. 45-46. 
del sector pueden eximirse de aprender a pensar y a razonar sobre las consecuencias morales del progreso técnico o de la conversión en producto de un determinado avance científico. Y, a la inversa, no sé si quién se especialice en la reflexión ética podrá hacerlo sin una base de cultura científica y económica.

Creo que el Renacimiento comprendió que esta integración de saberes es propia de momentos de transformación, de cambio de valores, de tiempos de encrucijadas donde la orientación no es fácil, y olvidarlo nos ha hecho perder algunas formas de aproximación al conocimiento que hoy echamos de menos. Efectivamente, en contextos de incertidumbre y complejidad como el actual, cuando reclamamos valores como la creatividad o aludimos a un «mundo incalculable»; cuando se nos advierte contra «la ilusión de la exactitud» y se hace «elogio de la inexactitud»; cuando lamentamos la "falta de autoexamen», la incapacidad de las personas para hacer «un examen crítico de sí mismas»; cuando unos reclaman el valor de las «descripciones densas» para describir las culturas humanas y otros proponen recuperar un conocimiento contextualizado; cuando alabamos la interdisciplinariedad, o cuando nos damos cuenta de que también lo «emocional» forma parte del conocimiento útil... aludimos, casi sin saberlo, a esa vía de conocimiento integral casi perdida, o al menos infravalorada. Quizá hemos olvidado que nuestros predecesores del XVI ya respondieron a esa inquietud, y también en tiempos de incertidumbre, apostando por un conocimiento que, además de ser «útil», proporcione «sentido» y sea capaz de integrar lo específico en lo sistémico, lo particular en lo general ${ }^{25}$.

\section{De cómo la política Se convirtió en Razón de Estado y de cómo ante la crisis DEL Estado No SABEMOS QUÉ HACER CON LA POLÍ́tica}

".no hay en el mundo tantas repúblicas como había antiguamente $y$, por consiguiente, no se ve en los pueblos el amor a la libertad que antes tenían" $(\text { Maquiavelo) })^{26}$

25 Sobre la introspección y el conocimiento de uno mismo, Nussbaum, M., Sin fines de lucro. Por qué la democracia necesita de las humanidades, Katz, Buenos Aires, 2010, pp. 75 ss. y Bauman, Z., Identidad, Losada, Buenos Aires, 2010, pp. 60 ss. Sobre el «mundo incalculable» y la "ilusión de la exactitud», InNERARITY,D., La democracia del conocimiento. Por una sociedad inteligente, Paidós, Barcelona, 2011, pp. 159 ss. y su artículo «Elogio de la inexactitud» publicado en El Diario Vasco, 29 de diciembre de 2010, p. 22 (también en http:// www.danielinnerarity.es/opinion-preblog/elogio-de-la-inexactitud/). Sobre las descripciones densas, GeERTZ, C., «Descripción densa: hacia una teoría interpretativa de la cultura», en: La interpretación de las culturas, Paidós, Barcelona, 2003, pp. 19-40. Sobre la recuperación de un conocimiento contextualizado, Toulmin, S., Cosmópolis. El trasfondo de la modernidad, Península, Barcelona, 2001, por ejemplo, pp. 124 ss.

26 Discursos sobre la primera década de Tito Livio, Alianza, Madrid, 1987, ed. de Martínez Arancón, A., Libro II, cap. 2, pág. 189. 


\section{Política frente a razón de Estado}

Volvamos otra vez a 1512 e iniciemos un segundo itinerario que nos conducirá al ámbito de lo político. Regresemos a la batalla de Prato y al pavor de los florentinos. Si en nuestro primer itinerario la imagen de partida era la mano de Dios dando vida a Adán, aquí nos centraremos en la mano de un paisano y coetáneo de Miguel Ángel, Nicolás Maquiavelo, escribiendo El Príncipe. Ese año de 1512 fue un auténtico annus horribilis para él. También el siguiente de 1513. Precisamente el episodio de Prato ya mencionado, causó tanto terror en los florentinos que claudicaron ante lo que era una de las pretensiones de la Liga Santa, la vuelta de los Medici al poder en Florencia. Como consecuencia, Maquiavelo se vio inmediatamente apartado del gobierno de la república toscana e incluso, al año siguiente, fue torturado como sospechoso de participar en una conjura contra los Medici. En una carta a su amigo Vettori, a finales de 1513 , le confiesa que lo único que le consuela en aquella coyuntura es «hablar» con los clásicos y "preguntarles la razón de sus acciones» ${ }^{27}$. En esos ratos de diálogo reconoce haber escrito un pequeño tratado De principatibus, que nosotros conocemos como El Príncipe. En nuestro imaginario tradicional, esta obra marca el inicio de la ciencia política moderna y anuncia un nuevo principio rector de esa política, la «razón de Estado». Entendible pero curioso, pues Maquiavelo no utiliza jamás el término "política» en esta obra; tampoco el de «razón de Estado». Intentemos bucear un poco más en el contexto que rodeó su escritura.

Aclaremos, de entrada, que en aquellos momentos no había ni Estados, ni naciones, ni soberanía ni, todavía, nada que se pareciese a una lógica política moderna. Particularmente, no había asuntos de Estado sino de Religión. La comunidad política por excelencia era la Cristiandad y el problema que se debatía era el de quién y cómo «encabezaba» ese cuerpo político en su dimensión temporal, pues algunos monarcas se sentían con la fuerza suficiente como para disputar ese rol al emperador. No por casualidad empleaban apelativos como el de «católico» o «cristianísimo» que ponían en evidencia sus pretensiones universales ${ }^{28}$. El Papa, poder espiritual, era tradicionalmente quien legitimaba que una guerra pudiera hacerse en nombre de Dios y de la

27 El párrafo completo es éste: «Llegada la noche regreso a casa y entro en mi estudio; y en el umbral me despojo de aquella ropa cotidiana, llena de barro y lodo, y visto prendas reales y curiales; y, decentemente vestido, entro en las antiguas cortes de los hombres antiguos, donde, recibido amorosamente por ellos, me alimento de esa comida que es sólo mía; ya que nací para ella; allí no me avergüenzo de hablar con ellos y preguntarles la razón de sus acciones; y ellos, por su humanidad, me responden; y durante cuatro horas de tiempo no siento tedio alguno, olvido todo afán, no temo la pobreza, no me asusta la muerte; me transfiero del todo a ellos». Tomo la traducción de VIRoLI, M., La sonrisa de Maquiavelo, Tusquets Editores, Barcelona, 2000, pág. 183.

28 Sobre la noción de "Imperio» vienen muy a cuento las reflexiones de FERNández Albaladejo, P., «Imperio e identidad: consideraciones historiográficas sobre el momento imperial español», en SEMATA, Ciencias Sociais e Humanidades, 2011, vol. 23, pp. 131-148. 
Cristiandad. No es de extrañar, por tanto, que la estrategia de esos monarcas fuese presionar, acercarse a Roma, influir en el nombramiento de los Papas, e incluso discutir a éste sus criterios ${ }^{29}$, y por eso Italia era un escenario de continuos enfrentamientos.

Desde otro punto de vista, el mapa de Europa era un conglomerado de ciudades-estado, provincias, pays, countries, landers, cantones o similares que cuidaban celosamente sus tradiciones, usos y costumbres, que contaban con instituciones propias y, en algunos casos, con una tradición de autoadministración y lucha por sus libertades ${ }^{30}$. Se discutía mucho sobre cuál era la fórmula ideal de gobierno, pues entre estos territorios se intercalaban otros —señorías, principados, ducados... - de costumbres más cercanas al dominio de raigambre feudal y no tanto a una autoadministración colectiva. Maquiavelo lo resumió en el debate entre repúblicas y principados: o se vivía libre o sometido a un príncipe $^{31}$, aunque evidentemente eran muchos los grados intermedios que se podían constatar. Pero lo más característico del momento era la expansión de las monarquías. Incluso a costa de la autonomía o neutralidad de muchos territorios. Algunos «príncipes» consolidados por la tradición - y haciendo suya la máxima «rex est imperator in regno suo»— se habían convertido desde la Baja Edad Media en cabezas estables de sus reinos ${ }^{32}$ y, a partir de ahí, habían logrado vincular — con diferentes fórmulas y reconociendo estatus diferenciados-a otros territorios con tradiciones, costumbres e instituciones propias. Algunas monarquías eran ya en el XVI auténticos conglomerados de reinos y territorios, monarquías compuestas, que, como decíamos, eran capaces de discutir al emperador el papel de cabeza de facto de la Cristiandad.

En estas monarquías - y en comunidades territoriales que resistieron el empuje de aquéllas- podemos reconocer el anuncio de los futuros estados-nación soberanos, del sistema westfaliano que se impondrá tras 1648. Pero, a comienzos del XVI, todavía se luchaba por encabezar la Cristiandad, no por dividirla. Fue el fracaso de este intento, tras un largo periodo de Guerras de Religión,

29 Como cuando el monarca francés, tras la firma del Tratado de Tordesillas de 1494 y tras las Bulas Papales que le siguieron, preguntó irónicamente «en virtud de qué cláusula del testamento de Adán se repartían españoles y portugueses el mundo todavía desconocido» (Romano, R.; Tenenti, A., Los fundamentos del mundo moderno. Edad Media tardía, Renacimiento, Reforma, Siglo XXI, Madrid, 1971, p. 178).

30 Gerhard, D., La Vieja Europa. Factores de continuidad en la historia europea (10001800). Alianza, Madrid 1991, pp. 65-71.

31 Maquiavelo, N., El Príncipe, ed. de H. Puigdoménech, Tecnos, Madrid 2011, I, p. 9.

32 Llegando a conseguir en algunos casos una notable identificación entre rey y comunidad (véase por ejemplo CaLASso, G., «Procesos de integración en Europa (siglos XVXVIII). Conquistas y uniones, aceptaciones y rechazos», en: Floristán, A. (coord.), 1512. Conquista e incorporación de Navarra. Historiografía, derecho y otros procesos de integración en la Europa renacentista, Planeta, Barcelona 2012, pp. 19-27, especialmente pp. 24-25). Sobre las formas de integración en la monarquía véase, en esta misma obra, el artículo de ARRIETA, J., «Formas de unión de reinos: tipología y casuística en perspectiva jurídico-política (siglos XVI-XVIII)», pp. 89-125, así como los recogidos en la cuarta parte del mismo volumen, que pemiten establecer comparaciones entre varios casos europeos. 
lo que trajo Westfalia, la Europa de los estados soberanos. Dos años antes de los Tratados, Hobbes planteó en su De Cive las primeras bases firmes para un tratamiento racional, no mediado por la religión, de la política ${ }^{33}$. Pero, antes, mientras el interminable conflicto religioso que se iniciará tras la Reforma convencía a unos y a otros de que la unidad era imposible, hubo que reconducir algunas bases fundamentales de la vida política.

En primer lugar, es muy interesante observar cómo el sentimiento de identidad, de pertenencia se polarizó en torno a la lealtad político-religiosa, más allá de la pertenencia a una comunidad territorial determinada. El incremento de la movilidad (comercio, viajes, guerras...) venía multiplicando los contactos culturales y provocando tanto el refuerzo de lo que se sentía como propio como el distanciamiento respecto de lo percibido como ajeno. Al salir fuera del lugar de origen, los elementos comunes como el idioma reforzaron el sentimiento de pertenencia y la búsqueda de solidaridades, a la vez que acentuaron la rivalidad con otros grupos, como testifica perfectamente, por ejemplo, la actividad de los vascos en la Corte, en Sevilla o en América. El sentimiento de pertenecer a la Cristiandad se compatibilizaba perfectamente con la idea de pertenencia a una comunidad más próxima al individuo. Pero, efectivamente, la creciente complejidad que las disputas en clave religiosa iban tomando en el seno de la Cristiandad provocó que la vinculación de reinos, repúblicas, señoríos o cualquier otro tipo de territorios a una de las grandes opciones para encabezar la Cristiandad fuese también tomado progresivamente no como un signo de identidad más, sino como el signo de identidad prioritario, puesto que proporcionaba las claves del alineamiento político-religioso en el seno de esa Cristiandad. Es así como el complejo y plural mapa de las identidades europeas comenzó a «resumirse» en torno a la lealtad político-religiosa, y es así como algunos gentilicios como «españoles» $\mathrm{o}$ «franceses» se consolidaron sobre otros ${ }^{34}$. Aunque no todavía en el XVI, en los siglos siguientes se impondrán casi en exclusiva estas expresiones identitarias hasta concebirlas como civilizadas y racionales frente a otras que se tendrán como menores, regionales, incluso bárbaras ${ }^{35}$. Lo que sí aparece ya

33 El capítulo XV de El Príncipe es, sin duda, un antecedente prematuro de esta lógica. Hobbes fue perfectamente consciente de que su obra suponía el inicio de la "filosofía civil», en una operación en busca del «conocimiento de la verdad», de la «razón de las acciones humanas con el mismo grado de certeza con el que se conocen las razones de las dimensiones de las figuras» y del "principio adecuado» para conocer dichas acciones, absolutamente hermana de la búsqueda de certezas que había emprendido Descartes por las mismas fechas (Hobbes, T., El Ciudadano, ed. de Rodríguez Feo, J., CSIC; Madrid, 1993, pp. 2-3; también la pág. XI de la Introducción).

34 Sobre este asunto, es imprescindible GIL, X., «Un rey, una fe, muchas naciones. Patria y nación en la España de los siglos XVI y XVII», en: ÁlvareZ-Ossorio, A.; García, J. B. (eds.), La Monarquía de las Naciones. Patria, nación y naturaleza en la Monarquía de España, Fundación Carlos de Amberes, Madrid, 2004, pp. 39-76.

35 Para DE GaribaY, E., en la segunda mitad del siglo XVI, no era contradictorio escribir la más laudatoria «Historia Universal de los Reynos de España» proclamando a los cuatro vientos su compromiso con la Monarquía Católica, e identificarse con orgullo, en la portada 
en nuestra época es la rivalidad entre identidades, iniciando la tradición de tópicos, clichés y menosprecios al «extranjero» con que unos y otros se iban a obsequiar en los siglos posteriores ${ }^{36}$. En suma, la orientación de los sentimientos de pertenencia hacia la lealtad político-religiosa fue uno de los elementos que prepararon el terreno a la posterior división de la Cristiandad en Estados.

Otros pasos en esa dirección tendrían que esperar al estallido del drama de las Guerras de Religión ${ }^{37}$. Hasta entonces, la teoría política no salió de sus parámetros clásicos, y de discusiones sobre si la monarquía era o no una forma de gobierno mejor que la república. De hecho, la obra de Maquiavelo, vista en conjunto, no se sale de esos parámetros clásicos y supone ante todo una gran

de la misma obra, como «de nación cántabro», es decir, vasco (así lo declara en 1571 en la portada del tomo I de Los Quarenta Libros del Compendio Historial de las Chrónicas y Universal Historia de todos los Reynos de España. Hemos consultado la ed. de DE Comellas, S., Barcelona 1628). Sin embargo, en 1861, John Stuart Mill aconsejaba a vascos, bretones y escoceses - literalmente, ejemplos de «una porción inferior o atrasada de la especie humana»- dejarse absorber en el seno de naciones como la francesa o la británica —es decir, por un "pueblo altamente civilizado y culto»— pues consideraba esto mucho más ventajoso que «vivir adherido a sus rocas, resto semi-salvaje de los tiempos pasados, girando sin cesar en su estrecha órbita intelectual, sin participar ni interesarse en el movimiento general del mundo» (Mill, J. S., El gobierno representativo, ed. de García del MAzo, S., Administración de la Biblioteca Científico-Literaria - Librería de Victoriano Suárez, Sevilla-Madrid, 1878, cap. XVI, pp. 456-457. Puede encontrarse esta edición en http://fama2.us.es/fde/ocr/2006/ gobiernoRepresentativo.pdf; consulta realizada el 31 de julio de 2014).

36 Los ejemplos de comparaciones o de calificativos que comienzan a dispensarse entre miembros de una u otra nación son innumerables. Pueden verse algunos en HaLE, J. R., La civilización del Renacimiento en Europa. 1450-1620, Crítica, Barcelona, 1996, pp. 59 ss., o en Erasmo, o.c., pp. 120-121. Un ejemplo de la perplejidad que causa la diversidad es el célebre pasaje de Rabelais, F., (Gargantúa y Pantagruel, Planeta, Barcelona, 1984, I, cap. IX, pp. 5056) en el que Gargantúa intenta adivinar la procedencia de Panurgo hablándole en varios idiomas, entre ellos el euskera. En 1605, un obispo inglés se queja de las generalizaciones abusivas: «Los franceses son comúnmente llamados frívolos; los españoles orgullosos; los holandeses borrachos; los ingleses cuadrillas de negociantes; los italianos afeminados; los suecos cobardes; los bohemios inhumanos; los irlandeses bárbaros y supersticiosos; pero ¿existe alguien tan embrutecido para pensar que en toda Francia no haya ni un sólo hombre serio, en España ni uno humilde o en Alemania nadie que viva con sobriedad?» (recogido en Glacken, o.c. p. 417). Para atisbar el clima que comienza a predominar en la teórica comunidad de cristianos, permítaseme sólo recordar el caso del escritor italiano Campani, a quien el mal olor de los alemanes llevó a escribir irónicamente a un amigo: «me preguntarás qué hay en Alemania que sea digno de notarse: sin duda muchas cosas pero sobre todo el hecho de que aquí los muertos andan; y no creas que eso sucede por la bondad divina; sucede por costumbre... tú observarás que es interesante que los muertos vivan, que es bello, pero aquí yo, que estoy vivo, preferiría morir. Huelen mal, en efecto, los que andan, y si oliesen mal por muertos, no caminarían». (Recogido en Garin, El Renacimiento o.c., p. 57, del «Epistolarium» de Campani, lib. VI, I y ss).

37 Para todo lo que sigue Skinner, Q., El nacimiento del Estado, Gorla, Buenos Aires, 2003, o, más extensamente, Los fundamentos del pensamiento político moderno, 2 vols., F.C.E., México 1993. También Viroli, M., De la política a la razón de Estado. La adquisición y transformación del lenguaje político (1250-1600), Akal, Madrid, 2009.Y, sobre todo, Pocock, J. G. A., El momento o.c. 
reivindicación de las repúblicas, de la política entendida como arte del buen gobierno de la ciudad, protección de las libertades cívicas y desarrollo de las virtudes ciudadanas. Cuando en su retiro desencantado escribe El Príncipe, lo hace sobre lo que él concibe como una novedad que no se ajustaba a las reglas del juego político, sobre los «príncipes nuevos». Príncipes que adquirían dominios, que se imponían por la fuerza sobre comunidades y que se encontraban con el problema de dar solidez en el tiempo a esos dominios recién adquiridos. Dada su «novedad», esos príncipes no encontraban respaldo en la tradición y mucho menos apoyo en la población dominada; tampoco podían apelar a ninguna legitimidad, sólo a su poder. El ejercicio de la fuerza les permitía llegar, pero no mantenerse en el tiempo. Así, este príncipe quedaba a expensas, literalmente, de su virtuosismo, de su capacidad para enfrentarse al azar y a la Fortuna y para entender cuándo debía atenerse a reglas morales y cuándo no. Y estos problemas no los resolvía la teoría política; eran problemas de dominio y poder, no de política. Quizá por ello, cuando Maquiavelo desgrana las argucias de estos príncipes para mantenerse en el poder, nunca menciona el concepto de «política ${ }^{38}$, porque para él una cosa era la política, el arte de vivir y comprometerse en la vida de la república, y otra «mantener lo stato», el arte del poder.

Pero en el contexto de guerra endémica que siguió a la división de la Cristiandad, conservar «lo stato» se tornó objetivo casi exclusivo y el problema del poder comenzó a acaparar la discusión teórica. Se consideró - y no resultaba extraño en aquel contexto- que el hombre era incapaz de vivir en comunidad, que en realidad la «sociedad» era una suma de individuos movidos por sus propios intereses, lo cual llevaba de forma natural a la guerra y que ésta no podía evitarse si no existía un poder fuerte. Para ello, una vez establecida la necesidad de este poder se dedujo que debía ser soberano, esto es, exento incluso del cumplimiento de las leyes, y que no podría admitirse que una comunidad actuase al margen de o contra dicho poder soberano ${ }^{39}$, pues la historia ya habría dado suficientes muestras de que los individuos sólo actúan civilizadamente cuando se someten a un poder soberano ${ }^{40}$. Como conclusión de este nuevo imaginario político se argumentó que, dado que este poder era el único capaz de garantizar la seguridad y preservación de los individuos ${ }^{41}$, «razón de Estado» y «razón de

38 Y sí en sus «Discursos». Reparan en ello Viroli, M., De la política o.c., pp. 163-167, o Matteucci, N., El Estado moderno. Léxico y exploraciones, Unión Editorial, Madrid 2010, pp. 322-323.

39 Dunn , J., (Democracia. El viaje inacabado (508 a.C. - 1993. d.C.), Tusquets, Barcelona, 1995, pp. 300-301) nos ha recordado que la idea de Estado moderno fue fraguada «con el objetivo expreso de negar que cualquier población dada, cualquier pueblo, tuviera la capacidad de actuar por sí mismo o el derecho a hacerlo, con independencia de un soberano o contra éste».

40 SkINNER, Q., El nacimiento o.c., pp. 61-62.

41 Pagden, A., La Ilustración y sus enemigos. Dos ensayos sobre los orígenes de la modernidad, Península, Barcelona, 2002, pp. 53-54. Sobre el avance de la noción de «individuo» a lo largo de la Edad Moderna, van Dülmen, R., El descubrimiento del individuo. 1500-1800, Siglo XXI, Madrid, 2016. 
individuo» eran no sólo compatibles sino inseparables. En términos hobbesianos, quedaba demostrado que sólo se podía superar al monstruo de la guerra, «Behemoth», con el monstruo del Estado, «Leviatán», y que la construcción de la paz exigía la existencia de un poder fuerte, hacia dentro y hacia fuera. Había nacido el Estado moderno. Política, soberanía e identidad eran ya cuestión de Estado y no cuestión de religión o de comunidad ${ }^{42}$. Como nos ha recordado el medievalista Jacques Le Goff «la Europa actual aún no se ha curado de ello» ${ }^{43}$.

El resultado fue que «Estado» quedó unido a poder soberano e indisponible, y que "política» se confundió con «Estado» ${ }^{44}$, es decir, que política pasó a significar esencialmente ejercicio del poder y búsqueda de medios para ello; que política ya no sería nunca más el «arte» de vivir en libertad ni de desarrollar las virtudes ciudadanas; que sólo se podría hacer política desde el Estado y que donde no hubiese Estado ya no cabría política alguna.

Es cierto que enseguida se advirtió el peligro que encerraba Leviatán y que una evolución constitucional posterior orientó las relaciones Estado-Sociedad hacia la defensa de los derechos individuales y hacia la limitación de los poderes del Estado. Es cierto también que el pueblo acabó ocupando el lugar central que en principio ocuparon las monarquías absolutas y que se crearon puentes para la representación democrática y para la mediación política. Pero también es cierto que hacia finales del siglo XIX se veía ya con claridad que los puentes entre «Estado» $\mathrm{y}$ "Sociedad» tendían a fracturarse continua e irremediablemente, a pesar de todos los canales de representación establecidos; que el primero seguía desarrollándose a partir de las estructuras creadas para el absolutismo y que tenía que desplegar toda su fuerza para mantener el orden interno más veces de las que era deseable. Sólo el definitivo maridaje entre «Estado» y «Nación» permitió refundar la idea de origen de la comunidad, restituir la coherencia al conjunto y volcar las energías de Leviatán hacia fuera ${ }^{45}$. Pero con funestas consecuencias. En el siglo XX reapareció el peor de los leviatanes en forma de totalitarismo moderno, y Hannah Arendt tuvo que recordarnos que el mal estaba en el origen, en ese nuevo concepto de política que ya no orientaba los compromisos del ciudadano hacia lo común y lo público, sino hacia la obediencia política y hacia sus intereses particulares. En suma, que «razón de individuo" y "razón de Estado» habían producido un individuo políticamente apático y refugiado en su privacidad que resultaba ser el mejor caldo de cultivo para el totalitarismo ${ }^{46}$.

42 Clavero, B., Razón de estado, razón de individuo, razón de historia, Centro de Estudios Constitucionales, Madrid, 1991, p. 35 ss.; VIRoli, M., De la política o.c., pp. 317 ss. Para todo este proceso véase también MatTeucci, N., o.c., pp. 322 ss.

43 Le Goff, J., La vieja Europa y el mundo moderno, Alianza, Madrid, 1995, p. 39.

44 Véase VIROLI, M., De la política o.c., p. 340.

45 Schulze, H., Estado y nación en Europa, Crítica, Barcelona, 1997, pp. 82-84.

46 Queda perfectamente reflejado en su análisis del nazi Adolf Eichmann, en Eichmann en Jerusalén. Un estudio sobre la banalidad del mal, Lumen, Barcelona, 2000. Sobre su concepto de acción, véase La condición humana. Paidós, Barcelona, 1998. 
Cuando política se identificó con razón de Estado, el sentido de la lectura de El Príncipe cambió por completo. Dejó de ser un tratado sobre una novedad política. Ya nunca volvería a ser sólo una reflexión sobre cómo los «príncipes nuevos» se enfrentaban a la Fortuna, sino que pasó a considerarse el modelo de una nueva manera de entender la política más allá de las reglas morales, la referencia clásica para el arte de mantener «lo stato», que ahora era ya el objetivo de toda política. La manera en que el príncipe nuevo desarrollaba su estrategia resultaba - aunque no se reconociese abiertamente- más útil y cercana a las necesidades de Leviatán que cualquier descripción de la política como vida en la polis o en la república. Desde ese momento en que la excepción se hizo regla, Maquiavelo dejó de ser «maquiaveliano» y se convirtió en maquiavélico.

\section{Liberar al futuro liberando al pasado}

Cuando repasamos el segundo itinerario de nuestro viaje y todas estas imágenes sobre la política del Renacimiento, reparamos enseguida en el curioso paralelismo invertido entre aquella época y la nuestra. Entonces Europa se expandía en el mundo mientras estallaba internamente en mil pedazos; ahora se quiere recomponer internamente pero, valiéndonos otra vez de la metáfora de Galli, es el mundo el que «está por todas partes», y se nos viene encima, además literalmente, en pateras. Europa no se expande sino que se contrae. Y es notable que en ambas épocas se haya discutido mucho de estructuras políticas y de identidades. Lógico tratándose de épocas de refundación y transformaciones. De la renacentista salió un embrión que luego cuajó en el Estado como referencia exclusiva para la política moderna, con todo lo que llevaba aparejado en cuanto a soberanía e identidad. Pero si algo nos sugiere nuestro diálogo con la experiencia renacentista es que ese Estado soberano es histórico, luego contingente, tiene fecha de inicio y la puede tener de final, o al menos de considerable transformación. Si surgió como referencia en un entorno histórico muy determinado, que buscaba ante todo un orden, un cese de la violencia «interna», deberemos estar preparados para que sufra alteraciones sustanciales en otro mundo que ahora busca dar respuesta al enorme incremento de las interdependencias y de la movilidad de personas e información, así como a las crecientes demandas de reconocimiento. De hecho, hoy hablamos ya de «crisis del Estado» así como de una separación de lo que se había unido en 1648, de Estado y soberanía ${ }^{47}$. Pero no se trata de firmar la defunción del Estado, sino de estar atentos a su transformación para dirigirla y no dejarnos llevar, para aprovechar lo mejor de su historia y reformar lo que intuyamos menos deseable. No sabemos si el escenario hacia el que nos dirigimos será, como nos anticipó Held, «un orden político de naciones, ciudades y asociaciones ciudadanas al mismo

47 Fioravanti, M., «Estado y constitución», en: El estado moderno en Europa. Instituciones y derecho, Trotta, Madrid, 2004, pp. 13-43, especialmente p. 41. 
tiempo que de regiones y redes mundiales» ${ }^{48}$; no sabemos si las metrópolis globales de Sassen tendrán el protagonismo que se prevé49; no sabemos si la incapacidad de los Estados se traducirá en desviación de muchas decisiones a ámbitos no políticos, y por tanto en ningún caso democráticos ${ }^{50}$; o si una reactualizada noción de «imperio» podrá constituirse en alternativa a la crisis del Estado ${ }^{51}$. Demasiadas cuestiones que sólo se resolverán a largo plazo. Lo que parece seguro es que, como dice A.M. Hespanha, debemos comenzar por liberar al pasado de la tiranía de las categorías presentes para, así, abrir nuestras expectativas futuras. Hemos convertido en sujeto y esencia invariable lo que es contingente, producto de la historia, lo cual nos ha provocado una cierta cortedad de miras ${ }^{52}$. Como nos ha recordado Viroli, «la idea de que el corazón de la política es esa estructura impersonal de dominio denominada estado está tan firmemente arraigada en nuestra forma de pensar que cualquier otra concepción nos parece poco intuitiva y/o plausible» ${ }^{53}$. En suma, que ver estados cuando no los había, o verlos siempre inseparablemente unidos a otras categorías como nación o soberanía ha limitado notablemente nuestra capacidad de pensar el futuro.

Más allá de lo que ocurra con el Estado, si nuestra expectativa está en adaptar el humanismo al siglo XXI debemos detenernos también en otros asuntos clave: en lo que nos une y en lo que nos diferencia; en la gestión de lo que hemos definido como público y común, y en la gestión de la diversidad en entornos complejos.

En cuanto al primer tema, bien estará recordar que un día el concepto de política se refirió explícitamente a la responsabilidad del ciudadano, que no era otra que la de implicarse en la «cosa pública». Traducido a términos actuales, podríamos decir que ese significado originario del concepto nos recuerda que la participación en los asuntos que hemos decidido que sean comunes, públicos, es derecho y responsabilidad de la ciudadanía; que está bien que en sociedades complejas y especializadas actuemos mediante delegación, pero siempre a condición de que no olvidemos esa responsabilidad original. De hecho, creo que ese concepto tiene algo que ver con lo que reclamamos cuando pedimos más cercanía de la política a los ciudadanos, más participación, menos elitismo...

48 Held, D., Modelos de democracia, Alianza, Madrid 2001, pág. 398.

49 SAssen, S., Una sociología de la globalización, Katz, Buenos Aires, 2010, pp. 125 ss.

50 Como apunta Веск, U. desde las primeras páginas de su ya clásico ¿Qué es la globalización? Falacias del globalismo, respuestas a la globalización. Paidós, Barcelona, 1998, pp. 15 ss.

$51 \mathrm{Al}$ respecto, véanse las reflexiones de Fernández Albaladejo, P., «Imperio e identidad» o.c.

52 Hespanha, A. M., Storia delle istituzioni politiche, Jaca Book, Milano, 1993, p. 12. Otras voces que nos avisan de las limitaciones que supone pensar desde el Estado-nación soberano, en GALLI, o.c., pp. 9-10; SASSEN, o.c., p. 34; BECK, U., La mirada cosmopolita o la guerra es la paz, Paidós, Barcelona, 2005, pp. 38 ss.; Clavero, B., o.c., pp. 15 ss.; o Ruiz Vieytez, E., Juntos pero no revueltos. Sobre diversidad cultural, democracia y derechos humanos, Maia, Madrid, 2011, pp. 81-90.

53 VIRoli, De la política o.c., p. 320. 
Pero aquí tenemos varios problemas. El primero, el desprestigio y abandono de la política, ámbito en el que los individuos vemos con demasiada frecuencia sólo un espacio de negociación de nuestros intereses privados y de reclamación de nuestros derechos; el segundo, íntimamente ligado al anterior, nuestra incapacidad para pensar en lo "común», más allá de una tradicional división público/privado, que hoy resulta insuficiente ${ }^{54}$. No será fácil recuperar un espacio para categorías como ésta de «lo común» que quedaron relegadas en el nacimiento de la Modernidad. Recordemos que la «razón de Estado» y la «razón de individuo» nacieron de la disolución de lo comunitario y discurrieron paralelamente. Hay que reconocer, de entrada, que sin esta centralidad de la noción de individuo hoy no existiría nada parecido a los derechos individuales o a la igualdad ante la ley. Ha supuesto, por tanto, un innegable paso adelante desde el punto de vista del progreso humano. Pero esta «razón de individuo» nos ha conducido también a un imaginario en el que los «vicios privados» se convierten en virtudes públicas gracias a la intervención ordenadora del mercado $^{55}$. Dicho de otra manera, hemos deducido, quizá demasiado alegremente, que si cada individuo se centra en sus propios intereses y se consigue que la mayoría de individuos vean cumplidas sus expectativas ¿para qué necesitamos implicarnos en lo común? ¿no es suficiente con que el mercado ordene las preferencias y recompensas sociales en torno al criterio de utilidad? Creo que en este tipo de razonamientos podemos encontrar parte de las razones de fondo del alejamiento del ciudadano de la política.

En el terreno de la diversidad se ha hablado, no sin polémica, de la necesidad de políticas del reconocimiento. La historia del Estado-nación ha sido la del parcialmente frustrado intento de reconducir pluralidades a la unidad: afirmó unas y negó o desprestigió otras. Las identidades «de primera» tenían su particular Estado, y los Estados tenían identidades de primera y donde identidad nacional y Estado soberano no coincidían se les hacía coincidir. El campo de batalla en el que se convirtió Europa entre los siglos XVI y XX, la historia del colonialismo europeo ${ }^{56}$, o lo mucho que está costando en Europa «unirnos

54 Por ejemplo, InNerarity, D., (El nuevo espacio público, Espasa-Calpe, Madrid, 2006, p. 171 ss.) nos habla de «la insatisfacción frente a un modelo de articulación de los intereses privados y los intereses públicos demasiado elemental, poco adecuado a las actuales transformaciones sociales» y de cómo ello nos obliga a revisar nuestro concepto de «bien común». Sobre lo que argumentamos en este capítulo puede verse ahora del mismo autor La política en tiempos de indignación, Galaxia Gutenberg, Barcelona, 2015, especialmente pp. 215-238. Sobre la relación entre estado westfaliano e incapacidad para pensar en «lo común», véase Mattei, U., Bienes comunes. Un manifiesto, Trotta, Madrid 2013, pp. 28-29.

55 Véase Hirschman, A. O., Las pasiones y los intereses. Argumentos políticos en favor del capitalismo previos a su triunfo, Península, Barcelona, 1999.

56 Un perfecto ejemplo de lo que advierte CHAKRABARTY, D. (El humanismo en la era de la descolonización, Katz-Centro de Cultura Contemporánea de Barcelona, Buenos Aires-Barcelona, p. 14): que el racismo es la «respuesta por defecto» que hemos dado tradicionalmente al problema de qué hacer con las diferencias culturales entre grupos humanos. 
en la diversidad» y derribar barreras que son más mentales que físicas, nos indica bien a las claras a dónde condujo el camino de clichés y separaciones comenzado entonces. No deja de ser curioso que en la actualidad se estén proponiendo planteamientos cercanos a la pluralidad jurisdiccional que un día fue rechazada como contraria a la racionalidad política, que asistamos a una vuelta «a aquella originaria complejidad que dejaba convivir en su interior la búsqueda de la unidad y de su representación en el centro junto a la conciencia de una permanente pluralidad $\aleph^{57}$. No cabe duda de que esta evolución presenta perspectivas esperanzadoras - al menos en el ámbito europeo- para el reconocimiento político de la diversidad.

Pero el problema de la alteridad, de la gestión de la pluralidad, es hoy más complicado, porque, como hemos dicho antes, el «otro» está aquí y no en un rincón lejano del planeta; forma parte del «nosotros». Y es un otro que simboliza no sólo alteridad cultural sino también exclusión social. Así que necesitamos un lenguaje del reconocimiento que dé cuenta, sí, de diversidades pero a la vez de exclusiones, que sea el lenguaje de los marginados por la globalización. Porque la marginación en la era global se concibe como "ausencia de identidad», como «no estar», como ser arrojado del espacio social, y esto puede afectar tanto al que se queda sin trabajo en el mismo centro de una gran urbe, o a la que es menospreciada por razón de género, como a quien vive sin medios o «sin papeles» en un barrio marginal, o a un refugiado político. El reconocimiento, en tanto que devolución de identidad, supone la reintegración del marginado como sujeto de diálogo, como interlocutor válido en el espacio social ${ }^{58}$ y no es para nada casual que éste sea el lenguaje en el que formulan sus reclamaciones quienes piensan que «otra globalización es posible» ${ }^{59}$. Quizá muchas de nuestras carencias morales (sexismo, xenofobia, dominación étnica) no sean sino «precisamente la negación de este esquema de interlocución plena $»^{60}$. Quizá, en el fondo, seguimos siendo incapaces de contestar a la pregunta, terrible en su sencillez, que en el cuarto domingo de Adviento de 1511 fray Antón Montesino lanzó a los encomenderos que maltrataban a los indígenas: «¿Éstos, no son hombres?» ${ }^{61}$.

57 Fioravanti, o.c., pág. 38.

58 Sobre este concepto de reconocimiento véase Contina, A., Alianza y Contrato. Política, ética y religión, Trotta, Madrid, 2001. También Bauman, Identidad o.c., p. 89, y su advertencia de la p. 84. En la Introducción a este libro Benedetto Vecchi afirma que «la política sobre la identidad habla el lenguaje de los marginados a causa de la globalización» (p. 20).

59 Lema de los llamados «Nuevos Movimientos Sociales». Un buen resumen sobre éstos en Moreno, C.; IBARRA, P., «Indígenas, indigentes e indigestos. Los nuevos sujetos de la izquierda radical frente al neoliberalismo global», en: ANTón, J. (coord.), Las ideas políticas en el siglo XXI, Madrid: Madrid, 2011, pp. 180-195.

60 Etxeberria, X., Sociedades multiculturales. Mensajero, Bilbao, 2004, pág. 73.

${ }_{61}$ Puede consultarse el texto del sermón de Montesino en Soriano, E.; Maícas, P.; Gómez del Manzano, M. (eds.), España y América al encuentro. Textos y documentos desde los cronistas de Indias a los escritores contemporáneos (1492-1992), Biblioteca de Autores Cristianos, Madrid, 1992, n. 37, pp. 77-78. 
4. De cómo Concluye El VIAJE RESCATANDo Lo ESENCIAL DE ESTE DiÁlogo ENTRE EXPERIENCIA Y EXPECTATIVAS Y RECALCANDO AL LECTOR LA IMPORTANCIA DE «ESTAR EN LA ENCRUCIJADA»

"Estar en la encrucijada: ésa es la manera en que existe la sociedad humana» (Z. Bauman $)^{62}$

El humanismo moderno surgió en un complejo caldo de cultivo de discusiones y transformaciones que tuvieron lugar en el Renacimiento. Durante los siglos siguientes, optó por algunos de los caminos sugeridos o diseñados en ese momento complejo. Tomó forma y maduró hasta que el nuevo caldo de cultivo - el de las interdependencias globales- lo ha hecho entrar en crisis. Así que debemos replantear ese humanismo y volver a contestar a las preguntas básicas: ¿qué es el hombre? ¿hasta dónde llega su razón? ¿y su libertad? ¿qué modelo de relación queremos con los «otros»? ¿y con la naturaleza? ¿cómo preparamos, educamos, a nuestros jóvenes para que sepan enfrentarse a este nuevo mundo con renovados impulsos humanistas?

Un examen detenido al "caldo de cultivo» renacentista nos traslada, creo, una imagen sobre la que deberíamos reflexionar a la vuelta de nuestro viaje, cuando repasamos los videos y fotografías y seleccionamos las que vamos a enseñar a familia y amigos, cuando apostamos por unas imágenes que, a fuerza de verlas, quedarán grabadas en nuestra mente como «el» recuerdo, la memoria del viaje que siempre nos acompañará en nuestros futuros presentes. En suma, como una experiencia. En esa imagen, deberíamos retener que la sacralidad del hombre, la educación integral de la persona, el asombro respetuoso ante la naturaleza, el reconocimiento del «otro» o la política como práctica de la libertad civil, todas estas ideas, son parte de nuestro subconsciente cultural, de nuestro patrimonio colectivo, estuvieron ahí hace cinco siglos, en el «caldo de cultivo» inicial. No son, por tanto, opciones idealistas que surjan de la nada, ni a-científicas, ni anti-nada. Las razones y el modo en que las abandonamos, e incluso las olvidamos, deberían ser motivo para otros viajes y reflexiones de indudable valor para la hora actual. La manera en que las podemos hacer presentes en nuestros valores y políticas y las incorporamos y adaptamos progresivamente a nuestras necesidades concretas, a nuestro entorno global y a nuestro espacio finito, debería centrar buena parte de los debates actuales y futuros.

Para afrontar ese proceso de adaptación dos actitudes de partida me parecen imprescindibles. La primera la definiría como una labor de deconstrucción. Se trataría de relativizar el valor de algunas instituciones emblemáticas de la Modernidad, no verlas como «esencias» de nuestra historia sino como elementos contingentes, productos de nuestras propias decisiones y, por lo tanto, modificables. Deconstrucción no quiere decir demolición. Sería absurdo, por ejemplo, no reconocer que el Estado ha supuesto una continuación razonable de la polis como ámbito civilizador, al menos hacia dentro. Igualmente, sería

62 Libertad, Alianza, Madrid 1992, p. 143. 
absurdo olvidar que nunca en la historia una sociedad ha demostrado tal capacidad de producción de bienes como ésta que ha girado en torno a la «razón de individuo», al interés individual y al mercado. No se trata, por tanto, de demoler como de introducir unas sanas dosis de relativismo, necesarias para poder decidir con libertad.

La segunda la definiría como un «estar» o «sentirse» en una encrucijada. Un cruce de caminos es una situación en la que podemos y debemos decidir, no es un punto de una evolución lineal que sólo permite seguir una dirección preestablecida. Recordemos nuestro punto de inicio y el mensaje que nos dejaban Pico en su «Discurso» o Miguel Ángel, a través de esa mano que encendía la chispa vital: el hombre ha sido creado libre, con la capacidad y la obligación de decidir; ser libre y decidir es lo propio de la condición humana.

Se trata, por tanto, de un «estar en la encrucijada» que no es un «estar»pasivo sino atento, empático, previo a la acción, en actitud de remansar energía para proyectarse. Atendiendo así a uno de los grandes problemas de nuestro modelo cultural actual - la falta de introspección y autocrítica- y buscando un nuevo equilibrio entre compromiso y reflexión o, como hubieran dicho nuestros antepasados renacentistas, entre acción y contemplación ${ }^{63}$.

Un estar en la encrucijada que es también sentirse entre el pasado y el futuro, entre la experiencia y las expectativas. La Modernidad nos quitó de alguna manera la experiencia, porque concibió al pasado "como un país extraño» ${ }^{64}$, ajeno; nos convenció de que sólo había futuro y progreso y de que había que cortar radicalmente con el pasado. La posmodernidad, desencantada, nos ha dejado a su vez sin un futuro con el que ilusionarnos. Así que estamos en un presente escéptico, sin experiencia ni expectativas, sin sentido. Por eso, quizá la primera labor de un humanismo del siglo XXI sea volver a creer en la necesidad de establecer puentes entre ambas, en la necesidad de seguir reflexionando sobre nuestra trayectoria como seres humanos y de seguir creyendo en el progreso humano, de volver a tener alguna utopía.

Un sentirse en la encrucijada como lo hicieron los renacentistas, en debate y reflexión, con actitud creativa. Ni presos de un escepticismo que nos lleve a relativizarlo todo, ni movidos por esas falsas convicciones racionalistas que vienen acompañándonos desde el siglo XVII y que, como no podía ser de otra manera, han acabado convenciéndonos de que no es posible debatir sobre el

${ }^{63}$ Hay una clara relación entre esa falta de introspección y la incapacidad para la acción. La poca capacitación para el análisis interno deriva claramente en una incapacidad para el juicio crítico. BaUman, (Identidad o.c., pp. 60-63), por ejemplo, ha relacionado directamente la falta de introspección y de dominio sobre uno mismo con el desinterés cívico, es decir, con la incapacidad para proyectarse hacia fuera, y por tanto con nuestra incapacidad real para interesarnos por una política participativa. Nussbaum (o.c., pp. 76-78) ha denunciado que las personas que no son capaces de hacer un examen crítico de sí mismas resultan especialmente influenciables, y nos recuerda también que sin autoexamen no hay claridad, ni tampoco capacidad de argumentar, y sin ésta sólo hay sometimiento a la autoridad.

${ }^{64}$ Tomo la expresión, evidentemente, de Lowenthal, D., El pasado es un país extraño, Akal, Madrid, 1998. 
fondo de lo que hacemos sino sólo sobre la manera en que lo hacemos; es decir, de que no hay opciones, de que no cabe debate político sino gestión eficiente; en suma, del «fin de la historia». Al contrario, sentirse en la encrucijada sólo puede significar que queda mucho por debatir. Creo que nadie ha resumido mejor estas actitudes que Z. Bauman, cuando las asociaba precisamente con la libertad humana:

"La condición humana no es presa de su pasado... Cada momento de la historia es una intersección de caminos que llevan hacia varios futuros. Estar en la encrucijada: ésa es la manera en que existe la sociedad humana. Lo que parece en retrospectiva como un desarrollo inevitable` empezó a su vez al tomar un camino entre los muchos que se presentaban. El futuro difiere del pasado precisamente por dejar un amplio espacio para las elecciones y acciones humanas" ${ }^{65}$.

Es un buen texto para terminar. Espero que el viaje haya sido de su agrado.

Universidad de Deusto

José Angel Achón InsAusti

jachon@deusto.es

[Artículo aprobado para publicación en diciembre de 2016]

65 Bauman, Z., Libertad o.c., p. 143. 